\title{
Tropical Eastern Pacific Records of the Prickly Shark, Echinorbinus cookei (Chondrichthyes: Echinorhinidae) ${ }^{1}$
}

\author{
Douglas 7. Long, ${ }^{2,3,5}$ Fohn E. McCosker, ${ }^{3}$ Shmulik Blum ${ }^{4}$ and Avi Klapfer ${ }^{4}$
}

\begin{abstract}
Most records of the prickly shark, Echinorhinus cookei Pietschmann, 1928, are from temperate and subtropical areas of the Pacific rim, with few records from the tropics. This seemingly disjunct distribution led some authors to consider E. cookei to have an antitropical distribution. Unreported museum specimens and underwater observations of E. cookei from Cocos Island, Costa Rica; the Galápagos Islands; and northern Peru confirm its occurrence in the tropical eastern Pacific and, combined with other published records from the eastern Pacific, establish a continuous, panhemispheric eastern Pacific distribution.
\end{abstract}

The genus Echinorbinus contains two species, the bramble shark, E. brucus (Bonnaterre, 1788), from the Atlantic, Mediterranean, western Indian Ocean, and Australia, New Zealand, and Japan, and the prickly shark, E. cookei Pietschmann, 1928, known from Hawai' $\mathrm{i}$ and the western and eastern Pacific Ocean (Compagno et al. 2005, Last and Stevens 2009). The species are easily differentiated by visual examination: E. brucus possesses few, relatively large, sparse denticles, some of which are fused into plates, and E. cookei has numerous, close-packed, relatively small and stellate denticles that are not fused into plates (Compagno 1984).

Echinorbinus cookei was described from an adult male (220.3 cm total length [TL]) caught off Kaua'i, Hawai'i (additional Hawaiian captures and observations in Chave and

\footnotetext{
${ }^{1}$ Manuscript accepted 11 February 2011.

${ }^{2}$ Natural Sciences Department, Oakland Museum of California, 1000 Oak Street, Oakland, California 94607.

${ }^{3}$ California Academy of Sciences, 55 Music Concourse Drive, San Francisco, California 94118.

${ }^{4}$ Undersea Hunter Group, San Jose, Costa Rica.

${ }^{5}$ Corresponding author (e-mail: dlong@museumca .org).
}

Pacific Science (2011), vol. 65, no. 4:433-440

doi: $10.2984 / 65.4 .433$

(C) 2011 by University of Hawai'i Press

All rights reserved
Mundy [1994] and Crow et al. [1996]); it has subsequently been collected or observed off Japan (Taniuchi and Yanagisawa 1983, Kobayashi 1986), Taiwan (Teng 1958), Palau (Saunders 1984), Tonga (Randall et al. 2003), New Caledonia (Fourmanoir 1979), New Zealand (Garrick 1960, Garrick and Moreland 1968), northeastern and southeastern Australia (Last and Stevens 2009), and possibly the Gilbert Islands (Whitley and Colefax 1938). In the northeastern Pacific it was first reported from southern California (Hubbs and Clark 1945) and Guadalupe Island, western Mexico (Collyer 1953), but misidentified as E. brucus. Later captures from the western coast of North America extended the range of E. cookei from a northernmost record off Astoria, Oregon $\left(46^{\circ} 11^{\prime} \mathrm{N}, 124^{\circ} 00^{\prime} \mathrm{W}\right)$ (Pearcy et al. 1985), along the coast of central and southern California (Varoujean 1972, Crane and Heine 1992, Long 1994, Barry and Maher 2000), the Gulf of California (MarianoMeléndez and Villavicencio-Garayzar 1998, Aguirre et al. 2002, Ruiz-Campos et al. 2010), the Pacific coast of Mexico off Nayarit (21 ${ }^{\circ}$ $01^{\prime} \mathrm{N}, 105^{\circ} 40^{\prime} \mathrm{W}$ ) (Chavez-Ramos and Castro-Aguirre 1974), and a southernmost record off El Salvador $\left(12^{\circ} 51^{\prime} 83^{\prime \prime} \mathrm{N}, 89^{\circ} 36^{\prime}\right.$ $\left.18^{\prime \prime} \mathrm{W}\right)$ (Rojas et al. 2006). In the southeastern Pacific, E. cookei has been reported from a northern record off Huacho, Peru $\left(11^{\circ} 10^{\prime} \mathrm{S}\right.$, $77^{\circ} 50^{\prime} \mathrm{W}$ ) (Chirichigno 1963, misidentified as E. brucus), along the Chilean coast (Flores 
and Rojas 1979, Ruiz and Fernandez 1984, Meléndez and Meneses 1989, Meléndez et al. 1993), to a southernmost record in the Golfo de Arauco, Chile (33 $37^{\prime} \mathrm{S}, 73^{\circ} 20^{\prime} \mathrm{W}$ ) (Brito 2004), and also west of Chile from the Nazca Ridge (21 $30^{\prime} \mathrm{S}, 81^{\circ} 40^{\prime} \mathrm{W}$ ) (Golovan and Pakhorukov 1986, Parin 1991). This species has also been noted in fisheries checklists for other localities in the eastern Pacific (though all lack any specific location, depth, or specimen data), including continental Ecuador (Bearez 1996), Nicaragua (Sánchez 1997), Panama, Costa Rica, and Malpelo Island, Colombia (Compagno and Niem 1998, Robertson and Allen 2002). Echinorbinus cookei has been listed as a bycatch species in the coastal Colombian shrimp fishery (Puentes et al. 2007), although Mejía-Falla et al. (2007) noted the occurrence of this species in Pacific Columbian continental waters as "unconfirmed or dubious."

In light of the seemingly disjunct capture localities in largely temperate and subtropical marine areas, Hubbs (1952) suggested that $E$. cooke $i$ was a classic example of a shark with an antitropical distribution. Subsequent captures showed that E. cookei was more widespread in the Pacific basin than Hubbs realized, but the species was still largely absent from tropical waters of the eastern Pacific. Current published distributional maps for E. cookei also depict an apparently disjunct distribution between the Northern and Southern hemispheres, with equatorial waters seeming to be a barrier (Compagno 1984, Robertson and Allen 2002, Compagno et al. 2005, Last and Stevens 2009), but our data show this to be incorrect. We report on new records of $E$. cookei from the tropical eastern Pacific, as well as records from numerous other published reports that indicate that the northern and southern distributions of $E$. cookei do not represent disjunct antitropical populations but likely compose a continuous eastern Pacific population.

\section{MATERIALS AND METHODS}

Museum acronyms used in this study follow Eschmeyer (1998), and measurements follow Compagno (1984). All available locality, depth, and biological data that accompanied the museum specimens are presented. Material is housed in the ichthyological collections of the California Academy of Sciences (CAS), the Los Angeles County Museum of Natural History (LACM), the University of Costa Rica (UCR), and the United States National Museum of Natural History (USNM).

Underwater observations were made aboard the untethered manned submersibles Fobnson Sea-Link (JSL) at the Galápagos Islands (McCosker et al. 1997) and the DeepSee (DS) at Cocos Island, Costa Rica (Cortes and Blum 2008). The Jobnson Sea-Link is owned and operated by the Harbor Branch Oceanographic Institute (HBOI) of Fort Pierce, Florida; the DeepSee is operated by the Undersea Hunter organization of San Jose, Costa Rica. Both are outfitted with powerful exterior lighting and high-definition video and still cameras. Sharks were photographed and/or videotaped in situ, and the identifications were later reconfirmed by D.J.L. and J.E.M. Galápagos field observations are listed as JSL, followed by the dive number(s).

\section{RESULTS}

\section{Museum Specimens}

A total of eight specimens, including two from northern Peru and six from the Pacific coast of Costa Rica, is reported from four museum collections, and all represent previously unpublished localities for E. cookei (Table 1).

\section{Underwater Observations}

GALÁPAGOS ISLANDS (Figure 1, bottom): JSL dive 3952, immature, sex undetermined (approx. $130 \mathrm{~cm} \mathrm{TL),} \mathrm{over} \mathrm{a} \mathrm{rocky} \mathrm{bottom} \mathrm{at}$ $580 \mathrm{~m}$, temperature $8.29^{\circ} \mathrm{C}$, off Cabo Hammond $\left(00^{\circ} 27.99^{\prime} \mathrm{S}, 91^{\circ} 37.48^{\prime} \mathrm{W}\right)$, Isla Fernandina, 14 Nov. 1995; JSL 3957, immature, sex undetermined (approx. $190 \mathrm{~cm}$ TL), over a rocky bottom at $449 \mathrm{~m}, 8.40^{\circ} \mathrm{C}$, off Cabo Douglas $\left(00^{\circ} 17.53^{\prime} \mathrm{S}, 91^{\circ} 38.84^{\prime} \mathrm{W}\right)$, Isla Fernandina, 16 Nov. 1995; JSL 3967, adult female (approx. $270 \mathrm{~cm}$ TL), over a rocky bottom at $514 \mathrm{~m}, 8.54^{\circ} \mathrm{C}$, off Isla Darwin $\left(01^{\circ} 42.00^{\prime} \mathrm{N}, 92^{\circ} 00^{\prime} \mathrm{W}\right), 21$ Nov. 1995. 
TABLE 1

List of Museum Specimens Cited in This Study

\begin{tabular}{|c|c|c|c|c|}
\hline Museum No. & Sex & Length & Date Collected & Locality \\
\hline LACM $33827-31$ & Male & $67.4 \mathrm{~cm}$ & 29 June 1973 & $\begin{array}{l}\text { Trawled off Puntarenas City, Golfo de Nicoya, } \\
\text { Costa Rica }\end{array}$ \\
\hline UCR 589-1 & Male & $95.0 \mathrm{~cm}$ & 1972 & $\begin{array}{l}\text { Trawled off Puntarenas City, Golfo de Nicoya, } \\
\text { Costa Rica }\end{array}$ \\
\hline UCR $759-1$ (1 of 2$)$ & Male & $32.5 \mathrm{~cm}$ & 27 March 1973 & $\begin{array}{l}\text { Trawled at } 274 \mathrm{~m} \text { off Cabo Blanco, Peninsula de } \\
\text { Nicoya, Costa Rica }\end{array}$ \\
\hline UCR $759-1$ ( 2 of 2$)$ & Female & $37.0 \mathrm{~cm}$ & 27 March 1973 & $\begin{array}{l}\text { Trawled at } 274 \mathrm{~m} \text { off Cabo Blanco, Peninsula de } \\
\text { Nicoya, Costa Rica }\end{array}$ \\
\hline UCR 811-1 & Male & $78.5 \mathrm{~cm}$ & 23 June 1974 & Trawled at 311 m off Quepos, Costa Rica \\
\hline UCR 1361-2 & Male & $53.0 \mathrm{~cm}$ & 20 June 1980 & $\begin{array}{l}\text { Trawled at } 329 \text { m off Cabo Blanco, Peninsula de } \\
\text { Nicoya, Costa Rica }\end{array}$ \\
\hline USNM 201913 & Female & $152.4 \mathrm{~cm}$ & 3 June 1966 & $\begin{array}{l}\text { Trawled by the R/V Anton Brunn, cruise } 16 \text {, station } \\
627 \mathrm{~A} \text { at } 311 \mathrm{~m} \text { off Talara }\left(5^{\circ} 01^{\prime} \mathrm{S}, 81^{\circ} 25^{\prime} \mathrm{W}\right) \text {, } \\
\text { Peru }\end{array}$ \\
\hline CAS 58049 & Female & $118.8 \mathrm{~cm}$ & 3 June 1966 & $\begin{array}{l}\text { Trawled by the R/V Anton Brunn, cruise } 16 \text {, station } \\
27 \mathrm{~A} \text { at } 311 \mathrm{~m} \text { off Talara }\left(5^{\circ} 01^{\prime} \mathrm{S}, 81^{\circ} 25^{\prime} \mathrm{W}\right) \text {, } \\
\text { Peru }\end{array}$ \\
\hline
\end{tabular}

Note: Measurements are of total length (in cm); depth is listed in meters. Refer to text for museum acronyms.

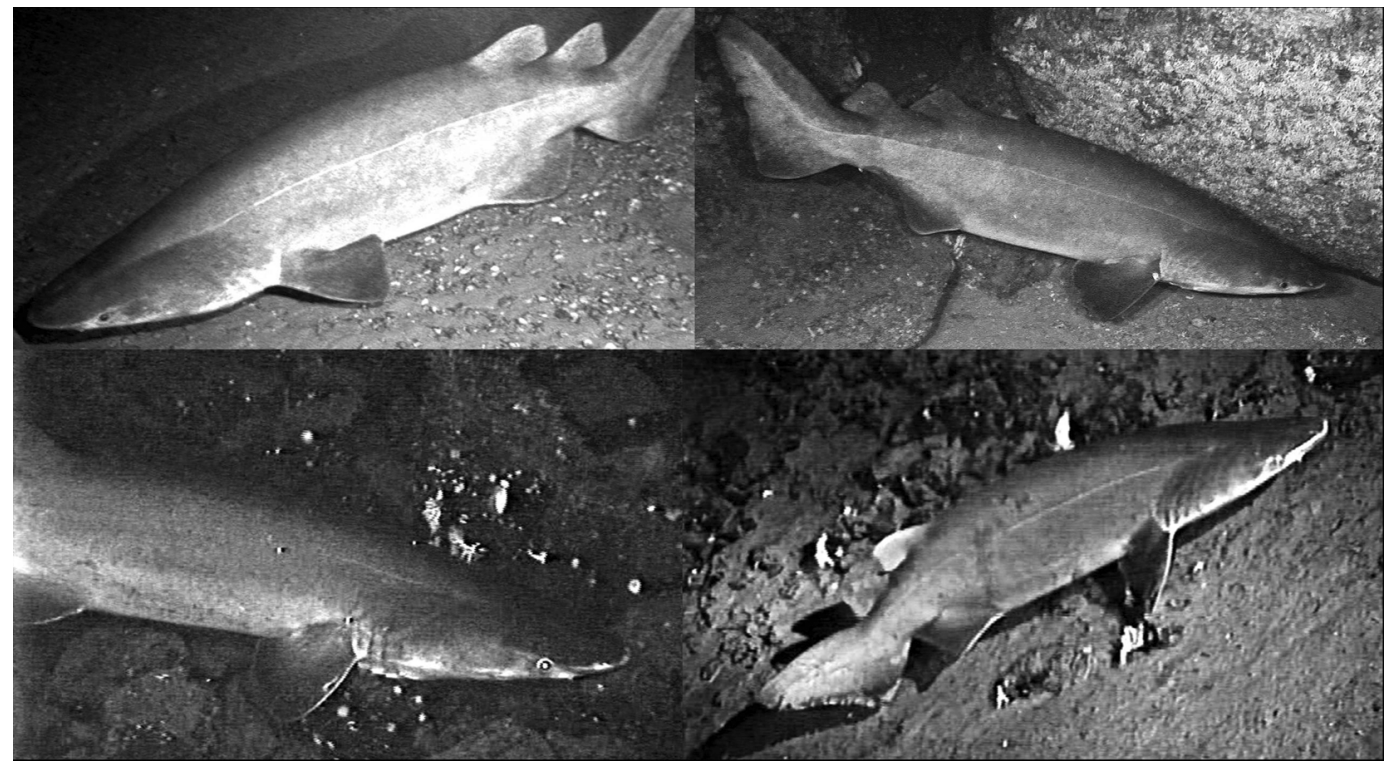

Figure 1. Photos of four different Echinorbinus cookei taken from manned submersibles. (Top row) Cocos Island, Costa Rica, ca. 305 m depth; (bottom row) (left) Isla Fernandina (dive 3957, 449 m depth), (right) Isla Darwin (dive 3967, 514 $\mathrm{m}$ depth), Galápagos Islands. See text for additional information. 
TABLE 2

Summary of Known Localities and Depths of Echinorbinus cookei in the Eastern Pacific Ocean

\begin{tabular}{|c|c|c|c|}
\hline Locality & Citation & Depth & No. of Specimens ${ }^{a}$ \\
\hline Oregon & Pearcy et al. (1985) & $439 \mathrm{~m}$ & $1(136.5 \mathrm{~cm})$ \\
\hline \multirow[t]{3}{*}{ Northern California } & Varoujean (1972) & $30-140 \mathrm{~m}$ & $19(109.5-280 \mathrm{~cm})$ \\
\hline & Crane and Heine (1992) & $15-35 \mathrm{~m}$ & $96+(300-400 \mathrm{~cm})$ \\
\hline & Dawson and Starr (2009) & $5-260 \mathrm{~m}$ & $25(170-270 \mathrm{~cm})$ \\
\hline \multirow[t]{3}{*}{ Southern California } & Varoujean (1972) & $100-280 \mathrm{~m}$ & $7(174.4-188 \mathrm{~cm})$ \\
\hline & Barry and Maher (2000) & $342 \mathrm{~m}$ & $1(175 \mathrm{~cm})$ \\
\hline & Long (1994) & $57-275 \mathrm{~m}$ & $7(135.7-200 \mathrm{~cm})$ \\
\hline \multirow[t]{2}{*}{ Guadalupe Island } & Collyer (1953) & $40 \mathrm{~m}$ & $2(267,295 \mathrm{~cm})$ \\
\hline & Long (1994) & $23 \mathrm{~m}$ & $1(280 \mathrm{~cm})$ \\
\hline Socorro Island & $\begin{array}{l}\text { Mariano-Meléndez and } \\
\text { Villavicencio-Garayazar (1998) }\end{array}$ & $120-130 \mathrm{~m}$ & $2(295,306 \mathrm{~cm})$ \\
\hline W. Baja California & Ruiz-Campos et al. (2010) & $127-181 \mathrm{~m}$ & $1(81 \mathrm{~cm})$ \\
\hline \multirow[t]{3}{*}{ Gulf of California } & $\begin{array}{l}\text { Chavez-Ramos and Castro-Aguirre } \\
\text { (1974) }\end{array}$ & $400-424 \mathrm{~m}$ & $2(68.5,93.5 \mathrm{~cm})$ \\
\hline & $\begin{array}{l}\text { Mariano-Meléndez and } \\
\text { Villavicencio-Garayazar (1998) }\end{array}$ & $144-160 \mathrm{~m}$ & $4(130-211 \mathrm{~cm})$ \\
\hline & Ruiz-Campos et al. (2010) & "near surface" & $1(294 \mathrm{~cm})$ \\
\hline Southwestern Mexico & Aguirre et al. (2002) & $132 \mathrm{~m}$ & $1(37.7 \mathrm{~cm})$ \\
\hline El Salvador & Rojas et al. (2006) & $180-357 \mathrm{~m}$ & $2(34.6,52.0 \mathrm{~cm})$ \\
\hline Costa Rica & This report & $274-329 \mathrm{~m}$ & $6(32.5-95 \mathrm{~cm})$ \\
\hline Cocos Island & This report & $180-350 \mathrm{~m}$ & $46(200-400 \mathrm{~cm})$ \\
\hline Galápagos Islands & This report & $449-514 \mathrm{~m}$ & $3(130-270 \mathrm{~cm})$ \\
\hline Peru & This report & $311 \mathrm{~m}$ & $2(118.8,152.4 \mathrm{~cm})$ \\
\hline \multirow[t]{5}{*}{ Chile } & Flores and Rojas (1979) & $300-340 \mathrm{~m}$ & $1(145 \mathrm{~cm})$ \\
\hline & Ruiz and Fernandez (1984) & $400 \mathrm{~m}$ & $1(135.5 \mathrm{~cm})$ \\
\hline & Meléndez and Meneses (1989) & $400-524 \mathrm{~m}$ & $2(81.3,135.5 \mathrm{~cm})$ \\
\hline & Meléndez et al. (1993) & $160 \mathrm{~m}$ & 1 (N/A) \\
\hline & Brito (2004) & $208 \mathrm{~m}$ & $1(107 \mathrm{~cm})$ \\
\hline \multirow[t]{2}{*}{ Nazca Ridge } & Golovan and Pakhorukov (1986) & $300-340 \mathrm{~m}$ & $2(205.5,235 \mathrm{~cm})$ \\
\hline & Parin (1991) & $345-540 \mathrm{~m}$ & N/A \\
\hline \multirow[t]{2}{*}{ Hawai'i } & Chave and Mundy (1994) & $360-420 \mathrm{~m}$ & N/A \\
\hline & Crow et al. (1996) & $177-370 \mathrm{~m}$ & $13(183-304.8 \mathrm{~cm})$ \\
\hline
\end{tabular}

${ }^{a}$ Measurements for total length (TL) in parentheses; those where number of specimens examined and/or measurements are not available are listed as N/A.

COCOS ISLAND, COSTA RICA (Figure 1, top): S.B. and A.K. have had 42 encounters with E. cookei since December 2005 while piloting the submersible DeepSee at Cocos Island. The sharks were observed over both soft and rocky sediments between 185 and $350 \mathrm{~m}$, generally offshore between $05^{\circ} 34.6^{\prime} \mathrm{N}, 87^{\circ}$ $03.6^{\prime} \mathrm{W}$ and $05^{\circ} 34.4^{\prime} \mathrm{N}, 87^{\circ} 03.9^{\prime} \mathrm{W}$. The majority of sharks were female (38 of 42$)$ and mostly single individuals (40 of 42). During one encounter four females were seen together; during the other the gender of the two individuals could not be determined. Estimated lengths of the females ranged between
250 and $400 \mathrm{~cm} \mathrm{TL}$, and the males were estimated to be $250 \mathrm{~cm}$ TL. The skin of the males was less scarred than that of the females.

\section{DISCUSSION}

Antitropical distributions of marine species occur where separate populations in the Northern and Southern hemispheres are divided by warmer tropical waters. These can be real patterns of distribution where a vicariant event, usually a change in ocean temperature or currents, divides an original range into two isolated populations (Stepien and Rosen- 
blatt 1996, Hillbish et al. 2000). However, some previously assumed antitropical populations are often the result of temperature preference where cold-adapted forms are found in much deeper waters than their shallower ranges in temperate areas (Randall 1981, Lindberg 1991). Earlier and seemingly disjunct distribution records of E. cookei led Hubbs (1952) to believe that the species had an antitropical distribution. The inference was that these panhemispheric populations existed in earlier times of cooler equatorial water, or that some E. cookei crossed the tropics during Pleistocene glacial periods, when equatorial waters were less extensive, by swimming into slightly deeper, cooler areas. Northern and southern populations were permanently separated as the tropics expanded during warmer interglacial periods into the disjunct populations seen today (Hubbs 1952).

Compagno (1984) described Echinorbinus cookei as a eurybathic species, ranging in depth from 11 to $415 \mathrm{~m}$, but additional captures have extended the known depth range from as shallow as $5 \mathrm{~m}$ off California (Dawson and Starr 2009) to $524 \mathrm{~m}$ off Chile (Meléndez and Meneses 1989), $540 \mathrm{~m}$ on the Nazca Ridge (Parin 1991), between 550 and $650 \mathrm{~m}$ off Japan (Kobayashi 1986), and our maximum depth observations from the Galápagos at 514 $\mathrm{m}$ (Table 2). Although most shallow-water records for E. cookei are from higher latitudes and deeper-water records are from lower latitudes, the species shows a broad depth range in the eastern Pacific (Table 2). Distribution of this species in low latitudes appears to be limited to deeper, cooler isotherms between $5.5^{\circ} \mathrm{C}$ and $11^{\circ} \mathrm{C}$ (Chavez-Ramos and CastroAguirre 1974, Kobayashi 1986); in the tropics it generally occupies deeper $(200+\mathrm{m})$ waters (Formanoir 1979, Saunders 1984, Chave and Mundy 1994, Crow et al. 1996). By combining our data with previously published records, we conclude that E. cookei is not an antitropical species. Instead, E. cookei is a panhemispheric species in the eastern Pacific and probably a circum-Pacific species that will undoubtedly be captured elsewhere in the Pacific basin. Thus, what seem to be apparent patterns of antitropical distributions in some marine species might initially be artifacts based on limited initial data. At least in the case of E. cookei, the addition of a wealth of data from subsequent specimen captures and observations in tropical areas has elucidated a more genuine distributional pattern.

\section{ACKNOWLEDGMENTS}

We thank the late S. Drogin and crew of the submersible DeepSee, and the staff of the Harbor Branch Oceanographic Institute for their operation of the Fobnson Sea-Link. We thank W. Bussing of the University of Costa Rica, J. Seigel of the Los Angeles County Museum of Natural History, S. Raredon and S. Jewett of the U.S. National Museum of Natural History, and D. Catania and M. Hoang of the California Academy of Sciences for assistance with the specimens and references. For assistance and permission to study in Ecuador, we thank the Subdirector de Pesca de Galápagos and the Directors of the Parque Nacional de Galápagos and the Estacion Cientifica Charles Darwin. We also thank the David and Lucile Packard Foundation and the Discovery Channel for grants and other assistance.

\section{Literature Cited}

Aguirre, H., V. J. Madrid, and J. A. Virgen. 2002. Presence of Echinorbinus cookei off central Pacific Mexico. J. Fish Biol. 61:1403-1409.

Barry, J. P., and N. Maher. 2000. Observations of the prickly shark, Echinorbinus cookei, from the oxygen minimum zone in Santa Barbara Basin, California. Calif. Fish Game 86:213-215.

Bearez, P. 1996. Lista de los peces marinos del Ecuador continental. Rev. Biol. Trop. 44:731-741.

Brito, J. L. 2004. Presencia del Tiburon martillo Sphyrna zygaena (Carcharhiniformes: Sphyrnidae) y nuevo registro del tiburon espinudo Echinorbinus cookei (Squaliformes: Squalidae) en San Antonio, Chile central. Invest. Mar. Valparaiso 32:141-144.

Chave, E. H., and B. C. Mundy. 1994. Deepsea benthic fish of the Hawaiian archipelago, Cross Seamount, and Johnston Atoll. Pac. Sci. 48:367-409. 
Chavez-Ramos, H., and J. L. Castro-Aguirre. 1974. Notas y observaciones sobre la presencia de Echinorbinus cookei Pietschmann, 1928, en el Golfo de California, Mexico. An. Esc. Nac. Cienc. Biol. Mex. 21:155164.

Chirichigno, N. 1963. Nuevos tiburones para la fauna del Peru. Ministerio de Agricultura, Servicios Pesquerias 19:1-20.

Collyer, R. D. 1953. The bramble shark (Echinorbinus brucus) at Guadalupe Island, Mexico. Calif. Fish Game 39:266.

Compagno, L. J. V. 1984. FAO species catalogue. Vol. 4. Sharks of the world: An annotated and illustrated guide of shark species known to date. Part 1. Hexanchiformes to Lamniformes. FAO Fish. Synop. 125:1249.

Compagno, L. J. V., M. Dando, and S. Fowler. 2005. Sharks of the world. Princeton University Press, Princeton, New Jersey.

Compagno, L. J. V., and V. H. Niem. 1998. Echinorhinidae: Bramble sharks. Pages 1211-1212 in K. E. Carpenter and V. H. Niem, eds. FAO identification guide for fishery purposes: The living marine resources of the western central Pacific. FAO, Rome.

Cortes, J., and S. Blum. 2008. Life to $450 \mathrm{~m}$ depth at Isla del Coco, Costa Rica. Rev. Biol. Trop. 56:189-206.

Crane, N. L., and J. N. Heine. 1992. Observations of the prickly shark (Echinorbinus cookei) in Monterey Bay, California. Calif. Fish Game 78:166-168.

Crow, G. L., C. G. Lowe, and B. M. Wetherbee. 1996. Shark records from longline fishing programs in Hawai' $i$ with comments on Pacific Ocean distributions. Pac. Sci. 50:382-392.

Dawson, C. L., and R. M. Starr. 2009. Movements of subadult prickly sharks, Echinorbinus cookei, in the Monterey Canyon. Mar. Ecol. Prog. Ser. 386:153-262.

Eschmeyer, W. N. 1998. Collection abbreviations. Pages 16-22 in W. N. Eschmeyer, ed. Catalog of fishes. Special Publication No. 1 of the Center for Biodiversity Research and Information, California Academy of Sciences, San Francisco.
Flores, H., and P. Rojas. 1979. Presencia de Echinorbinus cookei Pietschmann, 1928 frente a las costas de Chile (Pisces: Squalidae, Echinorhininae). Invest. Mar. Valparaiso 7:41-45.

Fourmanoir, P. 1979. Requins de NouvelleCaledonie: Nouvelles especes de requins trouves en Nouvelle-Caledonie. Nat. Caledon. 16:11-13.

Garrick, J. A. F. 1960. Studies of New Zealand elasmobranchii. Part 10. The genus Echinorbinus, with an account of a second species, E. cookei Pietschmann, 1928, from New Zealand waters. Trans. R. Soc. N. Z. 88:105-117.

Garrick, J. A. F., and J. M. Moreland. 1968. Notes on a bramble shark, Echinorbinus cookei, from Cook Strait, New Zealand. Rec. Dom. Mus. (Wellington) 6:133-139.

Golovan, G. A., and N. P. Pakhorukov. 1986. New records of rare species of cartilaginous fishes. J. Ichthyol. 26:117-120.

Hillbish, T. J., A. Mullinax, S. I. Dolven, A. Meyer, R. K. Koehn, and P. D. Rawson. 2000. Origin of the antitropical distribution pattern in marine mussels (Mytilus spp.): Routes and timing of transequatorial migration. Mar. Biol. (Berl.) 136:69-77.

Hubbs, C. L. 1952. Antitropical distributions of fishes and other organisms. Proc. 7th Pac. Sci. Congr. 3:324-330.

Hubbs, C. L., and F. N. Clark. 1945. Occurrence of the bramble shark (Echinorbinus brucus) in California. Calif. Fish Game 31:64-67.

Kobayashi, H. 1986. Studies on deep-sea sharks in Kumano-nada region. Bull. Fac. Fish. Mie Univ. 13:25-133.

Last, P. R., and J. D. Stevens. 2009. Sharks and rays of Australia. 2nd ed. Harvard University Press, Cambridge, Massachusetts.

Lindberg, D. R. 1991. Marine biotic interchange between the Northern and Southern hemispheres. Paleobiology 17: 308-324.

Long, D. J. 1994. Historical biogeography of sharks from the northeastern Pacific Ocean. Ph.D. diss., University of California, Berkeley.

McCosker, J. E., G. Merlen, D. J. Long, R. G. Gilmore, and C. Villon. 1997. Deep- 
slope fishes collected during the 1995 eruption of Isla Fernandina, Galápagos. Not. Galap. 58:22-26.

Mejía-Falla, P. A., A. F. Navia, L. M. MejíaLadino, A. Acero, and E. A. Rubio. 2007. Tiburones y rayas de Colombia (Pisces: Elasmobranchii): Lista actualizada, revisada y comentada. Bol. Invest. Mar. Cost. 36:111-149.

Mariano-Meléndez, E., and C. J. Villavicencio-Garayazar. 1998. Cuatro tiburónes y una raya en la costa noroccidental de México. Rev. Biol. Trop. 46:465467.

Meléndez, R., O. Gálvez, and A. Cornejo. 1993. Catálogo colección de peces depositada en el Museo Nacional de Historia Natural de Chile. Mus. Nac. Hist. Nat. Publ. Ocas. (Santiago de Chile) No. 47.

Meléndez, R., and D. Meneses. 1989. Tiburones del Talud Continental recolectados entre Arica $\left(18^{\circ} 19^{\prime} \mathrm{S}\right)$ e Isla Mocha $\left(38^{\circ} 30^{\prime} \mathrm{S}\right)$, Chile. Invest. Mar. Valparaiso 17:3-73.

Parin, N. V. 1991. Fish fauna of the Nazca and Sala y Gomez Submarine Ridges, the easternmost outpost of the Indo-West $\mathrm{Pa}$ cific zoogeographic region. Bull. Mar. Sci. 49:671-683.

Pearcy, W. G., J. Fisher, R. Brodeur, and S. Johnson. 1985. Effects of the 1983 El Niño on coastal nekton off Oregon and Washington. Pages 188-204 in W. S. Wooster and D. L. Fluhart, eds. El Niño North. Washington Sea Grant Program, University of Washington, Seattle.

Pietschmann, V. 1928. Neue Fischarten aus dem Pazifischen Ozean. Anz. Oesterr. Akad. Wiss. Math. Naturwiss. Kl. 27:297298.

Puentes, V., N. Madrid, and L. A. Zapata. 2007. Catch composition of the deep sea shrimp fishery (Solenocera agassizi Faxon, 1893; Farfantepaenus californiensis Holmes, 1900 and Farfantepaenus brevirostris Kingsley, 1878) in the Colombian Pacific Ocean. Gayana 71:84-95.

Randall, J. E. 1981. Examples of antitropical distribution and antiequatorial distribution of Indo-West-Pacific fishes. Pac. Sci. 35:197-209.
Randall, J. E., J. T. Williams, D. G. Smith, M. Kulbicki, G. M. Tham, P. Labrosse, M. Kronen, E. Clua, and B. S. Mann. 2003. Checklist of the shore and epipelagic fishes of Tonga. Atoll Res. Bull. 502:497-508.

Robertson, R., and G. Allen. 2002. Shorefishes of the tropical eastern Pacific: An information system. CD-ROM. Smithsonian Tropical Research Institute, Balboa, Panama.

Rojas, J. R., C. I. Fuentes, and N. R. Hernández. 2006. Echinorbinus cookei Pietschmann, 1928 (Chondrichthyes: Squaliformes, Echinorhinidae), primer registro en aguas de El Salvador, Pacifico oriental tropical. Rev. Biol. Mar. Oceanogr. 41:117-119.

Ruiz-Campos, G., J. L. Castro-Aguirre, E. F. Balart, L. Campos-Dávila, and R. VelezMarin. 2010. Nuevos ejemplares y nuevos registros de peces cartilaginosos (Vertebrata: Chondrichthyes) de la costa del Pacifico Mexicano. Rev. Mex. Biol. 81:363-371.

Ruiz, R., V. H., and J. Fernandez B. 1984. Primer registro de Echinorbinus cookei Pietschmann, 1928 (Pisces: Squaliformes: Squalidae) para Chile. Bol. Soc. Biol. Concepcion 55:175-176.

Sánchez, A. C. 1997. Listado taxonomico de las especies marinas identificadas en los océanos Pacífico y Atlántico (Caribe) de Nicaragua. Ministerio de Economía y Desarrollo, MEDE PESCA, Managua.

Saunders, W. B. 1984. The role and status of Nautilus in its natural habitat: Evidence from deep-water remote camera photosequences. Paleobiology 19:469-486.

Stepien, C. L., and R. H. Rosenblatt. 1996. Genetic divergence in antitropical pelagic marine fishes (Trachurus, Merluccius, and Scomber) between North and South America. Copeia 3:586-598.

Taniuchi, T., and F. Yanagisawa. 1983. Occurrence of the prickly shark, Echinorbinus cookei, at Kumanonada, Japan. Jpn. J. Ichthyol. 29:465-468.

Teng, H. T. 1958. Studies on the elasmobranch fishes from Formosa. Part 1. Eighteen unrecorded species of sharks from Formosa. Bull. Taiwan Fish. Res. Inst. $3: 1-30$. 
Varoujean, D. H. 1972. Systematics of the genus Echinorbinus Blainville, based on a study of the prickly shark Echinorbinus cookei Pietschmann. M.S. thesis, Fresno State College, Fresno, California.
Whitley, G. P., and A. N. Colefax. 1938. Fishes from Nauru, Gilbert Islands, Oceana. Proc. Linn. Soc. N. S. W. 63:282-304. 